\title{
Critical heritage studies beyond epistemic popularism
}

\author{
Rodney Harrison
}

A response to the recent debate piece in Antiquity by González-Ruibal et al., examining the role of epistemic popularism in critical heritage studies and public archaeology.

Keywords: cultural heritage, critical heritage studies, expertise, popularism, natural heritage

Alfredo González-Ruibal and his co-authors ('Against reactionary popularism'; 2018) offer some valuable criticisms of the implications of certain tendencies within public archaeology and critical heritage studies to valorise 'popular' understandings of the past over 'expert' ones. Nonetheless, I disagree with several of the points made. One of these is the authors' apparent characterisation of critical heritage studies as a field of research that predominately promotes what they term 'epistemic popularism'. As the author of one of the two citations given as representing critical heritage studies and its suggested dominance (Waterton \& Smith 2010; Harrison 2013), I would like to offer some comments. These concern the relative heterogeneity of critical heritage studies as an area of research in relation to questions of expertise and publics (which have formed core interests for heritage studies alongside questions of representational politics). I will also briefly outline my own position on these issues, which differ significantly from the ways in which the authors characterise those of the field more generally. I do so not only to point out the range of views on these matters and the discussions that have occurred in relation to them within critical heritage studies itself, but also because I think the overly simplistic characterisation of critical heritage studies in the text is not helpful in moving forward debate on these matters. This is because a significant number of scholars who work in heritage studies would find it difficult to see their work represented in the critique that is offered.

González-Ruibal et al. argue that public archaeology and heritage studies have tended towards forms of epistemic popularism: "What the People say is correct because it is they who say it. What makes a statement true is not the logical consistency of the statement, but who it is that utters it" (2018: 509). The Association of Critical Heritage Studies manifesto (ACHS n.d.) and the work of Smith (especially 2006; see also Waterton \& Smith 2010) are cited and discussed as examples of this tendency, and Smith and Campbell (2018) responded as the authors of the manifesto. In moving quickly from this characterisation of the field of research to the suggested solution to the issues raised, the article omits reference to the significant ongoing discussion and critique within critical heritage studies of these questions (e.g. Harrison 2013 on 'zoological multiculturalism'; Rico 2016, 2017 on 'stakeholders'; Bennett et al. 2017 on 'culture', 'stakeholders' and 'indigeneity'); and indeed, of the ACHS manifesto

* UCL Institute of Archaeology, University College London, 31-34 Gordon Square, London WC1H OPY, UK (Email:r.harrison@ucl.ac.uk) 
itself (e.g. Winter 2013; this has also taken place at the biannual ACHS meetings and in various other fora). It further largely bypasses the work of those who have, in different ways, taken a less explicitly advocative and/or more agnostic position towards their research subjects than those they discuss (e.g. Harvey 2001; Macdonald 2013; DeSilvey 2017). My own position on these matters (see Harrison 2013, 2015) —and indeed, for me, the whole point of critical heritage studies - is rather different to those précised. I suggest that all forms of heritage-making need to be scrutinised critically—not just 'expert' claims to heritage, but popular ones too. These critiques should not be limited only to 'cultural' heritage, but also extend to 'natural' heritage, which is frequently normalised and thus attributed a moral position that removes it from scrutiny and a thorough consideration of its implications (e.g. Harrison 2017; Breithoff \& Harrison 2018).

This is not a matter of valuing one form of heritage or one way of doing heritage over another. In relation to the arguments that the authors make in favour of educating publics, what is most important is exposing all of the processes by which heritage is made-both expert and popular-and thus allowing publics to understand them in their own social, historical, political and economic context. Publics are then able to make an informed decision, taking into account the implications of the arguments mobilised in the name of heritage (or archaeology, or any of the other historical, social or natural sciences), about which objects, places and practices might form the appropriate building blocks for the futures that they wish to construct individually and collectively, and which they might choose to neglect, ignore or resist.

I suggest that there are ways of being critical in relation to heritage that are not inherently advocative of either popular or expert knowledge claims, but which are also not disengaged from their own contemporary and historical, political, ecological and economic contexts, and how these have given rise to various claims to ownership (be they moral, legal or intellectual claims) of different forms of heritage. I see the general project of critical heritage studies as outlined here-of exposing and educating publics about the operations of (largely structural and systemic) forms of power in relation to these various truth claims that relate to 'culture', 'nature', 'past' and 'future', and the production of difference more generally—as one which could also be supported under the banner of the new public archaeology advocated by González-Ruibal et al., although perhaps in a slightly different manner to the one that they suggest.

\section{Acknowledgements}

Work on this article was supported by the Arts and Humanities Research Council (AHRC) Heritage Priority Area Leadership Fellowship (AH/P009719/1) (www.heritage-research.org) and the AHRC-funded 'Care for the Future: Thinking Forward Through the Past' theme Heritage Futures research programme (AH/M004376/1) (www.heritage-futures.org).

\section{References}

ACHS Association of Critical Heritage Studies. n.d. Available at:

http://www.criticalheritagestudies.org/ (accessed 20 September 2018).

(C) Antiquity Publications Ltd, 2018
Bennett, T., F. Cameron, N. Dias, B. Dibley, R. HaRrison \& I. JACKNIs. 2017. Collecting, ordering, governing: anthropology, museums, and liberal government. Durham (NC): Duke University Press. 
Breithoff, E. \& R. Harrison. 2018. From ark to bank: extinction, proxies and biocapital in ex-situ biodiversity conservation practices. International Journal of Heritage Studies. http://dx.doi.org/10.1080/13527258.2018. 1512146

DeSilvey, C. 2017. Curated decay: heritage beyond saving. Minneapolis: Minnesota University Press.

González-Ruibal, A., P. González \& F. CriadoBOADO. 2018. Against reactionary populism: towards a new public archaeology. Antiquity 92: 507-15.

https://doi.org/10.15184/aqy.2017.227

Harrison, R. 2013. Heritage: critical approaches. Abingdon: Routledge. https://doi.org/10.1093/oxfordhb/ 9780199602001.013 .021

- 2015. Beyond 'natural' and 'cultural' heritage: toward an ontological politics of heritage in the age of Anthropocene. Heritage \& Society 8: $24-42$.

https://doi.org/10.1179/2159032X15Z. 00000000036

- 2017. Freezing seeds and making futures: endangerment, hope, security, and time in agrobiodiversity conservation practices. Culture, Agriculture, Food \& Environment 39: 80-89.

https://doi.org/10.1111/cuag.12096
Harvey, D. 2001. Heritage pasts and heritage presents: temporality, meaning and the scope of heritage studies. International Journal of Heritage Studies 7: 319-38. https://doi.org/10.1080/13581650120105534

Macdonald, S. 2013. Memorylands: heritage and identity in Europe today. Abingdon: Routledge.

Rico, T. 2016. Technology, technocracy, and the promise of 'alternative' heritage values, in $\mathrm{H}$. Silverman, E. Waterton \& S. Watson (ed.) Heritage in action: 217-30. New York: Springer. - 2017. Stakeholder in practice: 'us', 'them,' and the problem of expertise, in C. Hillerdal, A.

Karlström \& C. Ojala (ed.) Archaeologies of 'us' and 'them': debating the politics of ethnicity and indigeneity in archaeology and heritage discourse: 38-52. Abingdon: Routledge.

SMith, L. 2006. Uses of heritage. London: Routledge.

Smith, L. \& G. Campbell. 2018. It's not all about archaeology. Antiquity 92: 521-22. https://doi.org/10.15184/aqy.2018.15

Waterton, E. \& L. Smith. 2010. The recognition and misrecognition of community heritage. International Journal of Heritage Studies 16(1-2): 4-15. https://doi.org/10.1080/13527250903441671

WINTER, T. 2013. Clarifying the critical in critical heritage studies. International Journal of Heritage Studies 19: 532-45. https://doi.org/10.1080/13527258.2012.720997 